\title{
Merosin-Deficient Congenital Muscular Dystrophy Type 1A
}

National Cancer Institute

\section{Source}

National Cancer Institute. Merosin-Deficient Congenital Muscular Dystrophy Type 1 A. NCl Thesaurus. Code C118783.

An autosomal recessive inherited congenital muscular dystrophy caused by mutations in the LAMA2 gene. It is characterized by severe hypotonia, muscle weakness, elevated levels of serum creatinine kinase, and white matter abnormalities. 